\title{
Dictynna
}

Dictynna

Revue de poétique latine

$8 \mid 2011$

Varia

\section{India, Egypt and Parthia in Augustan verse: the post-orientalist turn}

Grant Parker

\section{OpenEdition}

Journals

Édition électronique

URL : http://journals.openedition.org/dictynna/691

DOI : 10.4000/dictynna.691

ISSN : 1765-3142

\section{Référence électronique}

Grant Parker, «India, Egypt and Parthia in Augustan verse: the post-orientalist turn », Dictynna [En ligne], 8 | 2011, mis en ligne le 22 novembre 2011, consulté le 10 septembre 2020. URL : http:// journals.openedition.org/dictynna/691; DOI : https://doi.org/10.4000/dictynna.691

Ce document a été généré automatiquement le 10 septembre 2020.

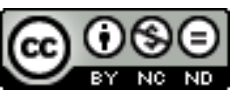

Les contenus des la revue Dictynna sont mis à disposition selon les termes de la Licence Creative Commons Attribution - Pas d'Utilisation Commerciale - Pas de Modification 4.0 International. 


\title{
India, Egypt and Parthia in Augustan verse: the post-orientalist turn
}

\author{
Grant Parker
}

1 Orientalism, in the sense pioneered by Edward Said in an eponymous book, is in many ways the obvious paradigm for considering western representations of the east. The work focuses on the modern period, basically nineteenth- and twentieth-century French and British artistic productions, yet it makes wide-ranging claims that stretch back to antiquity. ${ }^{1}$ In it, Said insists on a political, even military, framework for western fascination with the east at a scholarly or artistic level. This fascination has been manifested in a discourse, in which representations are inescapably informed by power relations. Orientalism has become a foundational text in cultural studies, still providing a direct point of departure more than three decades after it first appeared. ${ }^{2}$ Since 1978 the term 'orientalism', in English at least, cannot be used without invoking the book. To be sure, the term itself brings critical difficulties, for in common use it may denote either a critical approach fostered by Said or the very artistic productions that are the subject of Saidian critique. In ancient studies the book has had a visible impact, admittedly small and belated compared to modern literary studies. Nonetheless, its reception in classical studies has been very predominantly positive. ${ }^{3}$

2 Is Saidian Orientalism in fact a useful concept in the study of Augustan verse? The issue is much less resolved than scholarship would lead us to believe and is open to a fresh examination. The focus here will be on poetry of the Augustan age, with occasional reference to prose works of the same period. In these comments I would like to take up one particular aspect of Said's critique, namely the way in which different gentes and places are conflated in poetic discourse. In doing so I seek at some level to read ancient texts against modern theory, with the goal of critically evaluating the applicability of Orientalism as a paradigm. What are the differences between far and near in Augustan poetry, and how can we make sense of those differences? I shall argue, from a brief threefold case-study focusing on India, Egypt and Parthia, that 
Orientalism à la Said is only one approach, and a limited one at that. The term 'postorientalist' in the current title at once acknowledges the ongoing importance of Said's work and the search for ways beyond the impasses that have come to characterize its reception. Virgil provides the framework for this discussion : we begin with the shield of Aeneas near the end of Aeneid book 8, with its parade of foreign peoples, then more generally consider the Augustan literary presentation of the three gentes in turn, before canvassing an alternative possibility to Said's Orientalism. It is as part of the quest for alternatives that we return briefly to two other Virgilian passages, namely the travels constituting Aeneid 3 and the lines preceding the laus Italiae in the Georgics (2.109-35).

\section{Varia arma on the shield of Aeneas}

3 There are several reasons to use the shield of Aeneas as a point of departure. Coming as it does at a point of climax in the poem, this passage constitutes arguably the classic representation of foreigners in Augustan poetry, and it can easily be considered in relation to Augustus' manipulation of images. ${ }^{4}$ In particular, it does present an assemblage of foreign peoples, and it is the character of that assemblage that will demand our attention. As Hardie has shown in a cosmological context, the shield is an ekphrasis par excellence and an ideological centerpiece of the poem. Given its familiarity, only a few specific points need be made here. ${ }^{5}$ When we get to the description of the Battle of Actium, Antony is presented as both conqueror of eastern peoples and their military ally :

Hinc ope barbarica variisque Antonius armis,

victor ab Aurorae populis et litore rubro,

Aegyptum virisque Orientis et ultima secum

Bactra vehit, sequiturque (nefas) Aegyptia coniunx. (8.685-88)

Antony was hardly a 'victor', for his Parthian campaign of $36 \mathrm{BC}$ ended in disaster. ${ }^{6}$ The exact phrase 'ope barbarica' had already been used by Ennius, referring to Troy's allies : ${ }^{7}$ that use resonated here, showing the malleability of the concept of 'barbarus', also Antony's ambiguous status, and even Troy's. ${ }^{8}$ Grammatically parallel to the 'ope barbarica' is the variegated armour in which his allies are dressed ('variis ... armis'), an expression that functions in part as a transferred epithet. It is this variegation that deserves further consideration. Line 686 combines toponyms that are more or less generalized : 'Aurorae populis' and 'litore rubro'. The latter is more than the Red Sea, namely the northwest Indian Ocean of the Periplus Maris Erythraei of just a few decades later. ${ }^{9}$ Immediately following is 'Orientis'. The broad term 'oriens' carries both a cosmological and a topographic sense, ${ }^{10}$ here most productively to be taken in conjunction. Contrast the names of Egypt and Bactra, a land and a city. The repeated 'Aegyptia' adds point to the avoidance of Cleopatra's name - itself the standard poetic procedure $^{11}$ - especially as it follows, as it were, the interjection 'nefas'. Indeed, it is worth remarking that Antony himself is named in this passage, for we know from Dio (51.19.5) that in the triumph over his Roman enemies, Octavian went to great lengths to suppress the names of his Roman opponents. ${ }^{12}$ The rare use of Antony's Roman name seems just as pointed as the avoidance of Cleopatra's Graeco-Egyptian one.

Later, at 704-6, assorted foreigners take evasive action, displaying cowardice :

Actius haec cernens arcum intendebat Apollo

desuper ; omnis eo terrore Aegyptus et Indi,

omnis Arabs, omnes vertebant terga Sabaei. (8.704-6) 
6 Here, within two lines, we have the conflation of Egypt, India, Arabia and Sabaea, expressed in the typical poetic mixture of toponyms with ethnonyms, of collective singular with plurals. The battle description foreshadows the triumph, lines 714 following, which contains a great profusion of toponyms as the pace increases from 724 onward: these add enargeia to the climactic phrase 'victae longo ordine gentes' (722). The conquered nations exhibit different kinds of variety, audible and visible: 'quam variae linguis, habitu tam vestis et armis' (723). This explanatory line compactly outlines the criteria that typically determine ethnographic description $;^{13}$ 'variae' is a faint but telling echo of the earlier 'variis ... armis'. With the river-names of 726 following - Euphrates, Rhine and Araxes, that is, north amidst east - we should remember that such natural features were present at triumphs in personified form, as Appian tells us, ${ }^{14}$ a standard political use of synecdoche.It is no coincidence that rivers also played an important role in ancient maps, to judge from the Peutinger map and possibly the new Artemidorus papyrus. ${ }^{15}$ Indeed rivers featured in ancient descriptions of both Egypt and India. ${ }^{16}$

7 In the passage under discussion Egypt receives special prominence among foreign peoples, which is predictable enough in the context of Actium. Apart from the Egyptians, there is much conflation of foreigners, creating an intensified, vivid effect as if the triumphal procession speeds up as it passes by. The repeated adjective 'varius' is a mark of the vividness implicit in this passage.

8 These climactic lines are central to the current essay, even though their mention of the Parthians is indirect. Here is, prima facie, a good case of Orientalism: the forces of disorder, combined into an undifferentiated, even essentialized, other ; the dangerous east freeze-framed at a foundational moment of empire. Warfare dramatizes crosscultural confrontation, distancing Virgil's readership from Antony, once a Roman and now become an eastern foreigner. By his friends shall ye know him : here at Actium a Roman nobleman goes native, the furthest antithesis of the triumph. Here is, further, an encounter between foreign gods, troublingly theromorphic like Anubis (698), and the Roman ones, Neptune, Venus and Minerva. The political distinction between Rome and Egypt is mapped onto the religious domain.

\section{India, Egypt and Parthia compared}

9 If the shield contains several different gentes, with some conflation, it will be uesful to broaden our purview, so as to consider the poetic representation of three particular gentes, as a triple test case for the broader question framing this paper. In what ways can the various 'victae gentes' be disaggregated within Roman discourse? To what degree is it even possible to do so? The Saidian answer would be that conflation is central to the creation of orientalist discourse. In this section, in comparing the three gentes, I shall consider the social contexts in which Romans encountered these people, physically or otherwise, namely commodities, imperial ideology and wisdom.

10 Certainly the Egyptians were by far the best known to Romans, and the only ones to constitute a Roman province by the Augustan age $(30 \mathrm{BC})$ : there is of course Herodotean precedent, constituting the entire second book of the Histories, though that is itself an excursus in an account of Greco-Persian conflict. ${ }^{17}$ Egypt presents enormous variety in Greek and Latin texts. This image is largely negative, with the exceptions of 
Herodotus and Diodorus Siculus. ${ }^{18}$ In a Roman imperial context it is clear that in the short term Actium provided direct impetus for and was the focus of Augustan poetic ethnology. ${ }^{19}$ Nonetheless, the longer-term factor of religion is prominent in the poems, not only the more sympathetic account of the Isis cult in Tibullus 1.3 but also the hostility of Juvenal's 15 th satire..$^{20}$ The cult of Isis was at once distinctively Egyptian, as Virgil reminds us in a strongly gendered way (696f.), and something panMediterranean : its diffusion, via Delos and Attica by the fourth century BC, and present in Italy by the late second century (evidenced in the Palestrina Mosaic, linked with Fortuna), is something unmatched before the advent of Christianity. The variety of responses over time on the part of the Roman state is in itself remarkable. ${ }^{21}$

11 The mosaic would seem to suggest that the priorities expressed in the literary discourse are skewed - and this brings us to the first of the three contexts. For Egypt produced not only weird religious paraphernalia such as the sistrum but also commodities, including a huge percentage of the metropolis' food supply. It comes as a surprise, therefore, that the nutritional lifeline between Nile and Tiber is largely passed over by literary texts and also by coins. Roman fascination for things Egyptian, even if focused on esoterica, took place against a background noise of trade, not only of grain but of papyrus - the single most important material form of literature in this period. Certainly obelisks were highly visible symbols of power, but it was the humbler grain exports that sustained the city from day to day. In the end, Egypt is a special case in that it presents a literary image of great complexity, largely negative; its basic commodities are at the edge of visibility, much less than one might have expected from, say, the new Cambridge Economic History of the Greco-Roman World.22 Grain, so important to Rome's relation with Egypt, represents a remarkable case of nonrepresentation. ${ }^{23}$ Egypt's role in the Roman economy thus appears to be expressed indirectly rather than directly, if one is to consider obelisks and other objects more elaborate and more monumental than coins. ${ }^{24}$

12 By contrast, in the case of poetic representations of India, commodities and their supposed effects are central. Poets emphasize luxury goods, such as precious stones and pepper, whereas the Periplus of the Erythraean Sea shows that everyday items such as low-quality fabrics were part of the same cargoes, again attracting less attention. ${ }^{25}$ From a Mediterranean consumer's point of view, it must have been hard to distinguish the exact origins of merchandise, and in practice that is unlikely to have been the decisive point. It appears that, as in many societies, ancient Roman commodities had value depending on their supposed origin: the farther, the more valuable, within a kind of phenomenological economics. ${ }^{26}$ It is not merely Pliny the Elder that frets over the corrupting effect of those commodities in the metropolis : his concern is shared also by the poets. Horace even mentions an Indian slave at the dinner with Nasidienus, something reminiscent of the Periplus. ${ }^{27}$

13 Parthia and Parthians feature in Augustan poetry in a military context, part of a political discourse. This is well and good, but neglects their role in the long-distance trade that brought so many commodities from Asia to the Mediterranean. The firstcentury AD geographical work the Parthian Stations of Isidore of Charax points to such trade activity. Even if it is misleading to talk of 'caravan cities' or an integrated Silk Road it is still clear that land routes linked the Roman empire with south and central Asia no less than sea-routes. ${ }^{28}$ Alexandria and the Egyptians were thus not the only conduit of Rome's Asian trade. 
14 With the Parthians we come to a second ethnological context, which we may describe as imperial discourse. On the cuirass of the Prima Porta Augustus there is a vivid representation of the return of the standards. ${ }^{29}$ This is humbug, in that Augustus in 20 BC obtained the standards from Carrhae through diplomacy rather than warfare..$^{30}$ However, so much had Crassus' defeat festered in Roman minds that the task of vengeance had rested first with Julius Caesar, but he was denied the opportunity. ${ }^{31}$ When Augustus claims vengeance we should sense less its actual realisation than the intensity and length of its expectation. ${ }^{32}$ Ovid seems to play along with the ruse of 'mission accomplished'. At Fasti 5.579-96 and 6.461-69 we see much apparent celebration. But in the second case, the same calendrical date, 9 June, celebrates both Junius Brutus' victory over the Callici in northwest Spain in 136 BC and Crassus' defeat - a juxtaposition that is not lost on Ovid. Surprising is Ovid's choice of topic : if books 5 and 6 were in progress by the time of relegatio in $\mathrm{AD} \mathrm{8}$, then the memory of the death of Gaius would have been still a touchy subject: it was in the course of his Parthian campaign of AD 1-4 that the prince fell ill and died, compromising Augustus' plans for his succession. ${ }^{33}$ Just a little later, Manilius builds up the Parthians as if a sizeable empire, ruling other eastern and southern people. Manilius is hampered only by the distasteful nomenclature :

Magna iacet tellus magnis circumdata ripis

Parthis et a Parthis domitae per saecula gentes,

Bactraque et Aethiopes, Babylon et Susa Ninosque,

nominaque innumeris vix complectanda figuris. $(4.802-5)^{34}$

15 The notion of Parthia as 'another world', here within a larger cosmological frame, is later matched by Tacitus. ${ }^{35}$ But the visual dossier warns us against taking such discourse too literally. Parthians are subject to a wide range of presentation, sometimes in a military context. Among different types of Parthian image, the 'beautiful oriental' is notable and cannot be written off as the product of ethnocentric prejudice. Rather, it reveals demonstrable idealization, especially when linked with youthfulness. As Rolf Michael Schneider has shown, the othering of Parthians in plastic arts is complex, offering no simple, symmetrical opposite to Roman identity. ${ }^{36}$ By the same token, for Strabo at the beginning of his Geography the Arsacid empire is a source matching the Roman as a generator of topographical information. ${ }^{37}$ It is in such settings that any binaristic vision of Rome-versus-Parthia proves misleading.

16 The third context concerns the mystique that surrounds holy persons and other instances of barbarian wisdom ; but it will not detain us, since it applies to prose rather than verse. In the case of India, brahmans and naked philosophers are an important part of the Alexander story. Herodotus' Egypt is peopled by priests and other religious experts. Indeed, wisdom is most readily conceived at the edges of the known world. ${ }^{38}$

All in all, the Parthians are part of Roman imperial discourse, a looming but abstract presence. ${ }^{39}$ They are not linked to commodities, even though other evidence suggests they were involved in long-distance trade. India is merely on the fringes, as the source of luxury commodities, and as such would become caught up in the moralizing discourse of the later first century AD. Even more so than Parthia, India constitutes an abstract field of possibility, an 'oneiric horizon' ${ }^{40}$ for Trajan, India would be the ultimate object of conquest, enabling emulation of Alexander. Dio describes the sickly Trajan arriving at the Arabian Gulf, viewing cargo boats sailing to India, wishing he was young enough to proceed to India à la Alexander. ${ }^{41}$ This passage is a significant articulation of imperial desire, linking real commerce with impossible military dreams. 
It is the further development of sentiments found among the Augustans, and was made at a time when there was less political peril attached to the emulation of Alexander.

Each foreign people has its own ethnological moment : a particular historical point in relation to which they are firmly and discernibly imprinted on Roman minds. But the temporal distance of these moments from the Augustan age is varied: in the case of India, Alexander's expedition lay furthest in the past, and indeed it is clear that the idea of India was largely frozen in that early Hellenistic period. In the case of Parthia and Egypt, both the disaster at Carrhae and the victory at Actium had taken place within living memory : only the latter of these was resolved whereas in the former case resolution, ultio, is asserted speciously. These historical moments should be seen in counterpoint to an ethnographic tradition going back to Herodotus : that is no absolute continuity by any means, but a range of expectations. They are a counterpoint also to commerce that make little impression on the poetic radar screen. When there are similarities, these owe something to trade-routes : Egypt, via its major port Alexandria, funnelled goods from all over western Asia into the Mediterranean. From this viewpoint some overlap of characteristics is predictable enough.

\section{Orientalism revisited}

Orientalism à la Said is best geared to an us-and-them relation that happens at a distance: its immediate historical frame of reference is Napoleon in Egypt-who was accompanied by notions of Alexander the Great, and his own scientists and historiansas well as the nineteenth-century British empire. It is less suited to a situation in which foreign persons and objects come to the metropolis, in which a 'brownian motion' of ancient people was the norm rather than the exception. The overall view of movement within the ancient Mediterranean has changed with the appearance of The Corrupting Sea by Horden and Purcell (2000) : 'connectivity' is the mantra according to which, over the very longue durée, different groups remained connected, by land and sea, across the highly differentiated Mediterranean landscape. ${ }^{42}$ And it is clear, most concretely from David Noy's detailed study, that varied geographic origins were present in the city : actual persons who are epigraphically attested. ${ }^{43}$ It is also true that the past three decades have seen ever increased global flows, where cosmopolitanism risks banality and where postcolonial immigration is neatly if glibly summed up in the British activist slogan : 'We're here because you were there.' In fact, global history has moved beyond even that phase to one in which individual persons and families are internationally spread over networks which engender the ongoing circulation of goods, humans and ideas.

Saidian Orientalism tends to posit 'empire' as a monolith, a habit of expression and mind later manifested in Hardt and Negri's book of 2000. ${ }^{44}$ The historicist worry about the validity of such a broad characterization, when it glosses over the varieties of social control, of technology and even of ideology, is not something that can be easily overlooked. It would be more salutary, in ancient studies, to make no assumptions about continuity or of useful similarity between then and now : more intellectually productive is the comparative approach to the study of empires..$^{45}$

21 Furthermore, to what extent does Islam constitute an intellectual firewall in the critical study of antiquity? Histories of late antiquity have tended to conclude with a requisite chapter on the coming of Islam. ${ }^{46}$ But for classical philologists the Arabic language in 
particular has given Islam a status of otherness that defies negotiation. Now there is a real practical and intellectual problem here, given the difficulties of learning Arabic as a foreign language. ${ }^{47}$ But a priori it seems likely that Islam plays a part in the representational continuities Said claims existed from antiquity till the present. ${ }^{48}$ It is under the Ummayid caliphate that all the eastern and southern edges of the Mediterranean became a political unity, an orbis alter from a Roman perspective, even if Rome had meanwhile changed.

There is a further complication, which likewise cannot receive full consideration here but at least deserves to be flagged, in the relation between the south and the east of the Mediterranean. This is a variant on the question of conflation raised earlier. It is true that the southern littoral is much less populated, and much less agriculturally productive, with its proximity to desert. The broad point is that the underdeveloped south has seemed to take on characteristics of the east - the latter being long familiar in Greek literature and linked to ancient societies possessed of monumental architecture and writing technology. Since Homer's famous lines on the division of Ethiopians into east and west (Od. 1.22-24), there has been some sense of shared characteristics within Mare Erythraeum, the north-western Indian Ocean. ${ }^{49}$ In a Roman context the Carthaginians constituted a link between the south and the east. ${ }^{50}$

For Said in Orientalism south and east are obvious partners under the sign of Islam. Here his critique of western views may have brought him unintentionally close to that which is, in terms of political sympathy, its opposite. The Clash of Civilizations is the name of a North American best seller, ${ }^{51}$ and it has come to epitomize an approach that is invested in positing unchanging essences : civilizations (basically Islam versus Europe and the United States) have clashed because they have been and will always be at odds. This is antithetical to Said's approach. But it is also true that, ironically, Said himself tended to create a monolith of the West, ${ }^{52}$ something he tried to redress in his subsequent book Culture and Imperialism. Ultimately, however, he may be unwillingly caught up the very nexus he criticized. ${ }^{53}$

\section{Space and place: the experiential dimension}

Where to from here ? Far from any static vision of cross-cultural contact, a dynamic paradigm is needed for our times. On this basis it will be useful to canvass the concepts of space and place, even though they undoubtedly bring problems of their own. In the influential book by Yi-Fu Tuan, space and place are mutually defining: in the latter case, personal experience adds concreteness and limitations. ${ }^{54}$ Thus, in this stricter human geographical sense, space is where one might go whereas place is where one has been. These concepts are not symmetrical equals, but they have been used to emphasize different aspects of human interaction with the physical environment. In the Aeneid Tiberinus' confident prophecy gives a strong sense of place : 'hic locus urbis erit, requies ea certa laborum' (8.46). Indeed, we might say, prophecy leads to an overdetermined sense of place. This approach pushes us towards 'global flows' rather than collections of places - a difference that engages modern cultural geography. It is one thing to imagine the geographies of Strabo, Pliny or Pausanias as collections of places; they begin to look different if one seeks to find between the lines a sense of the interconnectedness of individual places, and of their dynamic relation. Even the 
seemingly static Peutinger map at some level represents a great deal of on-land movement, with its many roads..$^{55}$

Certainly Aeneid 3 contains a dynamic geography. Aeneas' route, via a mixture of mythological and more easily mappable places ${ }^{56}$ defines particular places via Aeneas' experiences. Yet at another level it also opens up a broader realm of Mediterraneanwide possibility. One could point to the contemporaneity of the Aeneid with Rome's expanded control over the entire inland sea. In this oblique sense, Aeneid 3 is simultaneously about Mediterranean space, namely Rome's military and economic domain following the Carthaginian wars. Thus the symbolic geography of the Aeneid is found as much in the shield of Aeneas as in the wanderings of book 3-itself a miniAeneid ${ }^{57}$-and indeed in Aeneas' calm journey up the Tiber (8.81-101) and tour with Evander of the future site of Rome (8.306-58). Whereas the shield of Aeneas, like its Homeric precedent ${ }^{58}$ offers an image of the cosmos, book 3 gives a highly dynamic view of the hero's movement within the broader Mediterranean. One might therefore argue that a sense of luxurious consumption attends representations of the east no less than imperialist desire. It is clear that, under the rubric of human geography, Aeneid 3 forms a revealing counterpoint to the shield of Aeneas.

Likewise, a brief comparison with the 26 lines (Georg. 2.109-35) preceding the laus Italiae is revealing. In the earlier work the products of the various lands are listed, in keeping with a deep sense that products are topographically defined (thus line 109). From the different kinds of territory preferred by trees (109-13), Virgil moves to particular territories : beginning with line 120, there is one line for Ethiopians, one for Chinese, four for India, then nine for the Medes, which we might broadly take as the Parthians. Line 125 is interesting in that it in effect conveys us from Indian trees to the Parthians, rather better known for their poison arrows. This list of thaumata, with its Golden Age resonances, is recapitulated just before the move to Italy itself : now in even more compact form we move by an amended route from Medes to Indians to Lydians (i.e., the river Hermus), to Bactra and India and Arabia (the mythical island of Panchaia). ${ }^{59}$ What we see here is not merely the direct comparison of Italy with the rest of the orbis terrarum, with eastern lands looming large ; there is also a submerged sense that exotic products had become commodities by the age of Augustus, products linked with places far away, but increasingly available within the cosmopolis.$^{60}$ The Georgics passage differs from the geography of the shield by virtue of the fact that Italy itself is present, or at least follows soon after ; further, it gives prominence to the natural world, including its products, something not present in the Aeneid passage.

\section{Conclusion}

27 In the matter of conflating eastern peoples, seen above in the hyperbole of the shield of Aeneas, Said's Orientalism has undoubted heuristic value. Indeed, the usefulness of the concept is, at an important level, beyond debate. Having deeply infused the very fabric of cultural studies, its legacy has been considerably complicated by its author's vigorous cut-and-thrust in debate ; by his political advocacy ; and not least by amicitia and inimicitia over the decades. ${ }^{61}$ Many critiques have been levelled at a narrowly empirical level, concerning detailed points of interpretation, in the course of which broader ideological and methodological considerations are obscured or lost. More importantly, there is no easy answer to the problem of what might come in place of the 
tainted representations, à la Said : it is not as if Indian, Parthian and Egyptian subaltern speech can be produced in ways that offset the (Greek and) Roman discourse of the exotic. Even for sympathetic critics there is the undeniable danger that the concept of Orientalism runs the risk of unsubtle deployment, something seen in uncritical use of the term 'empire'. ${ }^{62}$ Rather, cultural geography allows Roman encounters with eastern others to include admiration, desire, awe, pleasure; it links them to a highly fluid world defined as much by representations as by experiences. ${ }^{63}$

It would of course be a mistake to use the data sample here, drawn mostly from poetry, as a direct index of Augustan ideology, let alone the princeps' own views. That would be to miss the pragmatics of literary production and consumption. It would be better to imagine that the texts under discussion negotiated the hopes and fears of contemporary individuals, reflecting the public discourse of their times, but also at some level shaping it. Admittedly, it is hard to know exactly what level. Rather than any dichotomous vision, it would be more productive to attend both to spatialities, actual and imagined, by which people come together under the sign of imperial power, and to temporalities, in which particular images appear to be frozen in time. Care is needed to avoid a contradiction : the necessity of historicizing on one hand and that of seeking long-term resonance on the other. It is not clear that Said's book was able to resolve this contradiction.

The evidence adduced here, from Virgil and others, clearly reveals a real, live Roman notion of the east; it reveals a combination of commodities, imperial ideology and mystification within the same discourse. In the end, it is this combination that broadly distinguishes the east (and to some degree south) from the west and north of the empire. There is a transferability of qualities that are themselves well known from Herodotus' Egypt : India shares some of the features of Egypt, such as rivers ; it shares some of the features of Parthia, especially the need to be conquered. This, at least, is a way to read the world of the shield ; Aeneas' wanderings would seem to require a more flexible kind of mapping that centres on the concepts space and place and, not least, their complex relation..$^{64}$

Said's ongoing usefulness in the post-9/11 era has been to keep bringing attention to the contexts within which discourse was produced, and ultimately to encourage people to unthink supposed dichotomies of us-and-them, even more so than Said himself might have been able to do in his own work. ${ }^{65} \mathrm{~A}$ major difficulty with Orientalism is that, for all its radical critique, it fails to offer viable alternatives. At a tangent from Said I have preferred here to work with the related notions of space and place, where the difference between them foregrounds human experience and its varied temporalities. Cultural geography, itself originating in part in Saidian-inspired cultural studies, offers greater scope to identify fear and hope, celebration and loss - the range of responses projected by discourse onto a wide canvass. It is in this sense that narrow adherence to the Saidian paradigm may today be considered too limiting ; in this sense that a postorientalist approach may begin to set a new agenda. ${ }^{66}$ 


\section{BIBLIOGRAPHIE}

Adler, Eric (2008a), 'Late Victorian and Edwardian views of Rome and the nature of "defensive imperialism"', IJCT 15.2: 187-216.

Adler, Eric (2008b), 'Post-9/11 views of Rome and the nature of “defensive imperialism”', IJCT $15.4: 587-610$.

Al-‘Azm, Sadik Jala (1981), 'Orientalism and Orientalism in reverse', Khamsin 8.8 : 5-26.

Alcock, Susan E. et al., eds. (2000), Empires : perspectives from archaeology and history. Cambridge : Cambridge University Press.

Alcock, Susan E. et al. (2001), 'Sitting down with the Barrington Atlas', JRA 14 : 456-61.

Ashcroft, Bill and Pal Ahluwalia (1999), Edward Said : the paradox of identity. London : Routledge. Assmann, Jan (2010), 'Egypt', in Anthony Grafton et al., eds., The Classical Tradition. Cambridge Mass. : Harvard University Press, 299-302.

Beard, Mary (2007), The Roman Triumph. Cambridge, Mass. : Harvard University Press.

Bichler, Reinhold (2000), Herodots Welt. Der Aufbau der Historie am Bild der fremden Länder und Völker, ihrer Zivilisation und ihrer Geschichte. Berlin : Akademie.

Bowditch, P. Lowell (2011), 'Tibullus and Egypt : a postcolonial reading of Elegy 1.7', Arethusa $44.1: 89-122$.

Bowersock, G. W. (2005), 'The east-west orientation of Mediterranean studies and the meaning of north and south in antiquity', in W. V. Harris (ed.), Rethinking the Mediterranean. Oxford : Oxford University Press, 167-78.

Burke, Edmund, III and David Proschka (2008), Genealogies of Orientalism : history, theory, politics. Lincoln : University of Nebraska Press.

Eden, P. T. (1975), A Commentary on Virgil, Aeneid VIII. Leiden : Brill.

Campbell, Brian (1993), 'War and diplomacy : Rome and Parthia, 31 BC - AD 235', in John Rich and Graham Shipley, eds., War and Society in the Roman World. London : Routledge, 213-40.

Carrier, James G., ed. (1995), Occidentalism : images of the west. Oxford : Clarendon.

Casson, Lionel (1989), The Periplus Maris Erythraei : text with introduction, translation and commentary. Princeton : Princeton University Press.

Clay, Diskin and Andrea Purvis (1999), Four Island Utopias. Newburyport : Focus.

Cooley, Alison E. (2009), Res Gestae Divi Augusti : text, translation and commentary. Cambridge :

Cambridge University Press.

Dihle, Albrecht (1984), Antike und Orient. Gesammelte Aufsätze. Heidelberg : Winter.

Harley, J. B. and David Woodward, eds. (1987), The History of Cartography vol. 1 : Cartography in prehistoric, ancient and medieval Europe and the Mediterranean. Chicago : University of Chicago Press.

Drijvers, Jan Willem (1998), 'Strabo on Parthia and the Parthians', in Wiesehöfer, ed., 279-94.

Ferguson, Niall (2002), Empire : the rise and demise of the British world order and the lessons for global power. London : Penguin. 
Ferguson, Niall (2005), Colossus : the rise and fall of the American empire. London : Penguin. Gruen, Erich S. (1985), in Rolf Winkes, ed., The Age of Augustus. Providence, Rhode Island : Center for Old World Archaeology, 51-72.

Gruen, Erich S. (1996), 'The expansion of the empire under Augustus', CAH X (2nd edn.), 147-97. Gruen, Erich S. (2010), Rethinking the Other in Antiquity. Princeton : Princeton University Press. Gurval, Robert (1996), Actium and Augustus : the politics and emotions of civil war. University of Michigan Press : Ann Arbor.

Hardie, P. R. (1985), 'Imago mundi : cosmological and ideological aspects of the shield of Achilles', JHS $105: 11-31$.

Hardie, Philip R. (1986), Virgil's Aeneid : cosmos and imperium. Oxford : Clarendon.

Hardt, Michael and Antonio Negri (2000), Empire. Cambridge, Mass. : Harvard University Press.

Helms, Mary (1988), Ulysses' Sail : an ethnographic odyssey of power, knowledge and geographical distance. Princeton : Princeton University Press.

Hershkowitz, Debra (1991), 'The Aeneid in Aeneid 3', Vergilius 37 : 69-76.

Horden, Peregrine and Nicholas Purcell (2000), The Corrupting Sea : a study of Mediterranean history. Oxford : Blackwell.

Huntington, Samuel P. (1996). The Clash of Civilizations and the Remaking of World Order. New York: Doubleday.

Irwin, Robert (2006), Dangerous Knowledge : Orientalism and its discontents. Woodstock, NY :

Overlook.

Isaac, Benjamin H. (2004), The Invention of Racism in Classical Antiquity. Princeton : Princeton University Press.

Jocelyn, H. D., ed. (1967), The Tragedies of Ennius. Cambridge : Cambridge University Press.

Kerr, Malcolm H. (1980), Untitled review of Said (1978), International Journal of Middle East Studies $12.4: 544-47$.

le Goff, Jacques (1980), Time, Work and Culture in the Middle Ages, tr. Arthur Goldhammer. Chicago : University of Chicago Press.

Lloyd, Alan B. (2002), 'Egypt', in Egbert J. Bakker et al., eds, Brill's Companion to Herodotus. Leiden : Brill, 415-35.

MacFie, A. L., ed. (2000), Orientalism : a reader. Edinburgh : Edinburgh University Press.

Mattingly, D. J., ed. (1997), Dialogues in Roman Imperialism : power, discourse, and discrepant experience in the Roman Empire. JRA supplementary series no. 23. Portsmouth, Rhode Island : Journal of Roman Archaeology.

Meyboom, P. G. P. (1995), The Nile Mosaic of Palestrina : early evidence of Egyptian religion in Italy. Leiden : Brill.

Millar, Fergus (1998), 'Caravan cities : the Roman Near East and the long-distance trade by land', in Michael Austin et al., eds., Modus Operandi : Essays in honour of Geoffrey Rickman. London : University of London, 121-37.

Moatti, Claudia (2006), 'Translation, migration and communication in the Roman Empire : three aspects of movement in history', Classical Antiquity $25.1: 109-40$. 
Moore-Gilbert, Bart (1997), Post-Colonial Theory : contexts, practices, politics. London and New York : Verso.

Noy, David (2002), Foreigners at Rome : citizens and strangers. London : Duckworth.

Orazio : enciclopedia oraziana (1996-98), 3 vols. Rome : Istituto della Enciclopedia italiana.

Pelling, Christopher (1996), 'The triumviral period', CAH X (2nd edn.), 30-34.

Parker, Grant (2003), 'Narrating monumentality', Journal of Mediterranean Archaeology 16.2 :

193-215.

Parker, Grant (2004), 'Topographies of taste ; Indian textiles and Mediterranean contexts', Ars Orientalis $34: 19-37$.

Parker, Grant (2008), The Making of Roman India. Cambridge : Cambridge University Press.

Powell, Anton (2008), Virgil the Partisan : a study in the re-integration of the classics. Swansea : Classical Press of Wales.

Rickman, Geoffrey (1980), The Corn Supply of Ancient Rome. Oxford : Clarendon.

Riggsby, Andrew (2009), 'Space', in Andrew Feldherr, ed., The Cambridge Companion to the Roman Historians. Cambridge : Cambridge University Press, 152-65.

Said, Edward W. (1978), Orientalism. New York : Pantheon.

Scheid, John, ed. (2007), Res Gestae Divi Augusti. Paris : Les Belles Lettres.

Scheidel, Walter et al., eds. (2008), Cambridge Economic History of the Greco-Roman World. Cambridge : Cambridge University Press.

Schneider, Pierre (2004), Éthiopie et l'Inde. Interférences et confusions aux extrémités du monde antique. Paris.

Schneider, Rolf Michael (1998), 'Die Faszination des Feindes : Bilder der Parther und des Orients in Rom', in Wiesehöfer, ed., 96-146.

Schneider, Rolf Michael (forthcoming), 'The making of oriental Rome : shaping the Trojan legend', in P. F. Bang and C. Bayly (eds.), Universalism : genealogies of imperial culture and representation. Cambridge : Cambridge University Press.

Singh, Amritjit and Bruce G. Johnson, eds. (2004), Interviews with Edward W. Said. Jackson :

University Press of Mississippi.

Sonnabend, Holger (1986), Fremdenbild und Politik. Vorstellungen der Römer von Ägypten und dem Partherreich in der späten Republik und frühen Kaiserzeit. Frankfurt : Lang.

Spawforth, Antony (1994), 'Symbol of unity? The Persian Wars tradition in the Roman empire', Simon Hornblower, ed., Greek Historiography. Oxford : Clarendon, 239-47.

Takacs, Sarolta A. (1995) Isis and Serapis in the Roman World. Leiden : Brill.

Talbert, Richard J. A. (2009), 'P.Artemid. : the map', in Kai Brodersen and Jas' Elsner, eds., Images and Texts on the 'Artemidorus Papyrus'. Historia Einzelschriften 214. Stuttgart : Steiner, 57-64.

Talbert, Richard J. A. (2010), Rome's World : the Peutinger map reconsidered. Princeton : Princeton University Press.

Thomas, Richard F. (1982), Lands and People in Roman Poetry : the ethnographic tradition. Cambridge : Cambridge Philological Society. 
Treves, Piero (1996), 'Cleopatra', in Orazio : enciclopedia Oraziana, 3 vols. (1996-98), Rome : Istituto della Enciclopedia italiana, vol. I 691.

Tuan, Yi-Fu (1977), Space and Place : the perspective of experience. Minneapolis : University of Minnesota Press.

Vannicelli, Pietro (2001), 'Herodotus' Egypt and the foundations of universal history', in Nino Luraghi, ed., The Historian's Craft in the Age of Herodotus. Oxford : Oxford University Press, 211-40.

Varisco, Daniel Martin (2007), Reading Orientalism : Said and the unsaid. Seattle : University of Washington Press.

Vasunia, Phiroze (2003), 'Hellenism and empire : reading Edward Said', Parallax 9.4 : 88-97.

Versluys, Miguel John (2002), Aegyptiaca Romana : Nilotic scenes and the Roman views of Egypt.Leiden : Brill.

Vidman, Ladislaus, ed. (1969), Sylloge Inscriptionum Religionis Isiacae et Sarapiacae. Berlin : de Gruyter.

Viswanathan, Gauri (2001), Power, Politics and Culture : interviews with Edward W. Said. New York : Pantheon.

Webster, Jane and Nicholas Cooper, eds. (1996), Roman Imperialism : post-colonial perspectives. Leicester Archaeology Monograph no. 3. Leicester : University of Leicester.

West, D. A. (1990), 'Cernere erat : the shield of Aeneas', in S. J. Harrison, ed., Oxford Readings in Vergil's Aeneid. Oxford : Oxford University Press, 295-304 (orig. 1975/6).

Wiesehöfer, Josef, ed. (1998), Das Partherreich und seine Zeugnisse. The Arsacid Empire : sources and documentation. Historia Einzelschrifte 122. Stuttgart : Steiner.

Willcock, Malcolm M. (1976), A Companion to the Iliad. Chicago : University of Chicago Press.

Young, Gary K. (2001), Rome's Eastern Trade : international commerce and imperial policy, $31 \mathrm{BC}-\mathrm{AD}$ 305. London : Routledge.

Zanker, Paul (1988), The Power of Images in the Age of Augustus, tr. Alan Shapiro. Ann Arbor : University of Michigan Press.

\section{NOTES}

1. Said (1978: 56f.).

2. Hardly even the tip of the iceberg, the following offer a glimpse at the breadth of responses: Moore-Gilbert (1997); Ashcroft and Ahluwalia (1999); MacFie (2000); and Varisco (2007) - the last of these deploying humour as part of its own critique.

3. See for example Webster and Cooper, eds. (1996); Mattingly, ed. (1997); and especially Vasunia (2003); more skeptical is Adler (2008a).

4. Zanker (1988).

5. Still fundamental is the discussion of Hardie (1986: 336-76), who presents the shield as a 'blend of cosmic allegory and political ideology' (342).

6. Pelling (1996: 30-34). This turned the tide in that Octavian, who had up to then played second fiddle militarily, was victorious elsewhere at a time when Antony needed to reassert himself.

7. Enn. Scaen. 94 Vahlen, cf. Jocelyn (1967: 248f.) ad loc., and Eden (1975: 183) ad loc.

8. Schneider (forthcoming). 
9. Casson (1989: 7).

10. TLL s.v. 'oriens' vol. IX.2.1001.51 ff..

11. Treves (1996: vol. I 691).

12. By the same token, the name of Lepidus is studiously avoided, by periphrasis, at $R G 10$. See further Powell (2008: 15), with Scheid (2007: 45) and Cooley (2009: 150). Powell's analysis of Virgil's politics is hamstrung by an unsubtle adherence to the concept of 'propaganda'.

13. Thomas (1982); Parker (2008: 69-120).

14. Punica 66: 'Trumpeters led the advance and wagons laden with spoils. Towers were borne along representing the captured cities, and pictures showing the exploits of war: then gold and silver coin and bullion ...' (tr. H. White, Loeb vol. I 507). See further Beard (2007: 150).

15. Assuming that the 'Artemidorus papyrus' does in fact contain a map: note esp. the caution of Talbert (2009).

16. On the centrality of rivers, see Versluys (2002) and Dihle (1984) on Egypt and India respectively.

17. Among the more recent scholarship on Herodotus' Egypt, note especially Bichler (2000: 145-212) and Vannicelli (2001); Lloyd (2002) summarises his earlier, fundamental researches on Histories book 2 from an Egyptological standpoint.

18. Conveniently summarised by Assmann (2010:300).

19. Gurval (1996).

20. Note esp. Tib. 1.3.27-32; on Juvenal, see Courtney (1980: 590-612). Roman views of Egypt are well canvassed by Versluys (2002); in comparative frame by Sonnabend (1986) and Isaac (2004: 352-70). Isaac and now Bowditch (2011), on Tib. 1.7, emphasize ambivalence in Roman responses to Egypt.

21. Takacs (1995) plots the changing political fortunes of the Isis cult; on its diffusion, Vidman (1969). The Palestrina Mosaic is treated by Meyboom (1995).

22. Scheidel et al. (2008); still valuable is Rickman (1980). Two post-Augustan passages reveal Roman senatorial distress over Rome's dependence on Egyptian grain: Pliny, Paneg. 31.2 (failure of the grain supply through drought should remind Egyptians of their subordination to Rome); and Tacitus, Hist. 1.11 (the Roman state's irresponsibility caused the city's dependence). See further, Isaac (2004: 360f.).

23. One example of Augustan coinage shows that grain could depict provinces other than Egypt: e.g. Pergamene cistophorus, whose reverse has six ears of wheat, bound at their stalks, dividing the imperial name, AVGV-STVS. The obverse depicts Augustus, IMP CAESAR, and is dated to 27-26 BC. See Zanker (1988: fig. 36c).

24. Parker (2003: 208).

25. Casson (1989: 18).

26. On the value deriving from exotic status, see the fundamental anthropological work of Helms (1988); some Roman implications are explored by Parker (2004).

27. Hor., Serm. 2.8.14f.: 'procedit fuscus Hydaspes/ Caecuba uina ferens'.

28. Millar (1998); Young (2001).

29. Zanker (1988: 188f.).

30. Suet., Aug. 21.7. See further Campbell (1993: 213-40).

31. Dio 43.51.1.

32. Gruen (1985: 51-72).

33. Gruen (1996: 158-63).

34. 'Surrounded by these vast coasts [of the Red Sea] is the vast land of Parthia, and the nations vanquished over the ages by the Parthians, the Bactrians and Ethiopians, Babylon and Susa and Nineveh, and places where names could scarce adequately be conveyed by countless turns of speech.'

35. Ann. 2.2: 'petitum alio ex orbe regem'. 
36. R. M. Schneider (1998: 96-146); and idem (forthcoming).

37. Strabo 1.2.1 C49-51: 'Indeed, the spread of the empires of the Romans and of the Parthians has presented to geographers of to-day a considerable addition to our empirical knowledge of geography, just as did the campaign of Alexander to geographers of earlier times ... For Alexander opened up for us geographers a great part of Asia and all the northern part of Europe as far as the Ister River; ... and, again, the Parthians have increased our knowledge in regard to Hyrcania and Bactriana, and in regard to the Scythians who live north of Hyrcania and Bactriana, all of which countries were but imperfectly known to the earlier geographers.' (Loeb tr.). In practice, Strabo's coverage of Parthia is 'feeble', according to Drijvers (1998: 292). Be that as it may, the sentiment expressed by Strabo would appear to resonate with Said's concept of Orientalism.

38. Parker (2008: 251-307).

39. Isaac (2004).

40. Le Goff (1980: 189-200).

41. Dio 68.29.1: 'Then he arrived at the ocean itself, and having found out about its nature and having caught sight of a ship setting sail for India, he said he would definitely have crossed over to the Indians, were he still young. He began to cogitate the Indians and inquired into their affairs, and he deemed Alexander blessed.'

42. See also Moatti (2006).

43. Noy (2002).

44. Hardt and Negri (2000). It is ironic that a comparable deployment of the concept of 'empire' can be found in books of an entirely different political complexion: Ferguson (2002) and (2005). See Adler (2008b) for a survey of the image of Rome in recent American discourse about imperialism.

45. Note esp. Alcock et . (2000).

46. Nor does it help that an important recent synthetic study of alterity in the classical world does not venture beyond the early second century AD: Gruen (2010). No doubt there are reasons to justify this choice; still, its consequence is to leave Islam solidly out of the picture.

47. The present author has no bragging rights in this regard.

48. The Islamic faith per se receives little coverage from Said: Kerr (1980).

49. For late antiquity the Ethiopian-Indian link has become the subject of a major book: P. Schneider (2004). The lack of a developed ancient sense of a north-south axis may perhaps be attributed to the shape of the Mediterranean (Bowersock 2005).

50. A point that emerges nowhere more clearly than when Dido first addresses the shipwrecked Trojan party, making common cause - both are refugees from their east Mediterranean home while offering Carthaginian hospitality: Aen. 1.561-78.

51. Huntington (1996).

52. And compare also Carrier (1995).

53. This same criticism was made in an oft-cited paper by Al-'Azm (1981).

54. Tuan (1977); in a Roman context see now Riggsby (2009).

55. See Talbert (2010: 86f.): even if the symbolic dimension of the Peutinger map is rightly emphasized over any practical one, it is clear that the texture of the empire depends heavily on a network of roads. The Peutinger map would thus seem to represent movement at a more abstract level than has usually been imagined.

56. Mappable, that is, in the sense of the Barrington Atlas, which tends to favour the localities of Greek and Latin historiography but is also cognizant of excavations and surface survey: Alcock et al. (2001). As in the case of any map, choices need to be made as to what is included and excluded. 57. Hershkowitz (1991). 
58. For a diagram representing Achilles' shield, see Harley and Woodward (1987: 131); and Willcock (1976). Cf. Hardie (1985); and, for an attempt to represent the Virgilian shield visually, West (1990).

59. Euhemerus FGrH 63 F2 = Diod. Sic. 5.41.3 and 6.1.4; with commentary by Clay and Purvis (1999: 98-106).

60. Even Cicero had spent half a million sesterces for a table made of citrus-wood; Pliny knew of tables that cost more than double that (HN 13.92: sections 91-99 discuss citrus-wood tables). On timber as a high-end commodity, see W. Speyer, 'Holz', RAC 16 (1994) cols. 87-116.

61. Apart from Varisco (2007) see also Viswanathan (2001); Singh and Johnson (2004); Irwin (2006).

62. Contrast the careful and illuminating comparisons in Alcock et al. (2000).

63. Thus, a subtle study suggests that the Persian wars in Roman memory were not merely a way of legitimising the Romans' own dealings with Parthians, but also a way of coming to terms with the classical Greek world: Spawforth (1994).

64. It is in this latter sense of mapping that Dido's speech towards the end of book 1 may be understood: both the Trojans and Carthaginians are there located within Mediterranean space, focused at that point on a trajectory from the eastern to the southern Mediterranean.

65. Burke and Proschka (2008: 8) criticize Said for deficient attention to contexts.

66. For critical responses and other help I warmly thank Michèle Lowrie; Friedrich Spoth; the editor and anonymous readers of Dictynna; and audiences at La Sapienza and the University of Washington. The support of the Alexander von Humboldt Foundation - as well as my two host institutions in Munich, the Institut für klassische Archäologie (LMU) and the Thesaurus Linguae Latinae - is gratefully acknowledged. None of these parties should be thought to bear responsibility for the end result.

\section{RÉSUMÉS}

Orientalism, as a paradigm expounded by Edward W. Said, has been influential in literary studies. Here it is critically evaluated with reference to Augustan poetry, in relation to three different ethnic groups : Indians, Egyptians and Parthians. The shield of Aeneas is the point of departure. Some of the shortcomings of Saidian Orientalism can be circumvented by the adoption of concepts from human geography.

\section{INDEX}

Mots-clés : Egypt, human geography, India, Orientalism, Parthia, shield of Aeneas 